\title{
CROSS-BORDER REGION GORA TREASURE BETWEEN THE THREE STATES
}

\section{PHD.Behije Ibrahimi}

\section{South East European UniversityFaculty of Business and Ekonomics R. North Maqedonia-Tetov}

\begin{abstract}
The development of cross-border tourism has been done increasingly popular in recent decades and especially within the European Union through various programs and projects. This study focuses on the challenges and advantages that are directly related to cross-border and prospective visitor co-operatio and private entrepreneurs in this region. It will also analyze the attitudes of public actors towards the development of cross-border tourism and the challenges they face in cross-border cooperation. The main task of the scientific work is to recognize tourist potentials and their assessment as well as the current tourism development including prospects and problems which accompanies this development. Because of the importance that Tourism brings to the economy has become a priority of many states, being transformed in a global phenomenon, a key to integrating into the global mark. Tourism is also called the open door for international cooperation. Therefore our study will aim for the Gora Province to have positions in the regional and global market and be provided with a suitable brand. This region is distinguished for a rich and special culture and art. However there is a lack of research and studies as far as the role of local institutions and government is concerned with cross-border cooperation. For a qualitative approach, interviews with residents and surveys were used for tourists and locals with focus on current developments and challenges related to the development of cross-border tourism. Their analysis shows that there is significant interest how much is it to the development of tourism and the recognition of the area in the global markets.
\end{abstract}

Key words: Economic-social development, destination, community, cross-border cooperation etc. 


\section{INTRODUCTION}

Gora is a geographic region that extends into three states: in the northern part of Albania, in the southern part of Kosovo and northwestern Macedonia, including an area of $500 \mathrm{~km}^{2}$. Between this space passes the state border between the Republic of Albania and Kosovo. Gora at its borders traditional ethnography presents a geographical unity, economic and historical-cultural. Gora province has a very rugged terrain but rich with summer pastures, streams and forests. The basis of the economy has been farming and its subsidiary branches. The harsh and long winter and the fresh summer characterize its climate. . ${ }^{1}$ This region stretched in three states, besides agriculture and farming, their income is being provided with the development of mountain tourism . Today's tourism has become a priority for the economic development of different countries of the world. This closely related to the economic effects, social and environmental which brings him to a certain place This is supported by the conclusion reached by the World Tourism Organization which concludes that "Tourism is one of the priority sectors of the economy for developing countries in progress'. From conceptual point of view tourism is defined as: 'Activities of persons traveling or staying in places. Outside their usual environment (ambient), but not more than a year for entertainment, business and other purposes (WTO and UNSTAT, 1994). In recent decades, tourism has been developed and ranked in an important factor in the context of sustainable economic development. So tourism is one of the most important economic sectors. Moreover, as is well known, border cooperation is motivated mainly by the desire to achieve high standards of living, ensuring peace, overcoming customs barriers and curbing other factors, which hindered the free movement of people for economic, social and political purposes. The five components of Tourism that are researched by our study are: 1 . Tourist attractions in the Gora province (Based on Nature, Culture, Events, and Activities), 2. Marketing and Promotion, 3. Tourist Zone Infrastructure. 4. Tourist hospitality, 5. Tourist Service.

\section{Purpose and objectives of the study}

The purpose of this study is to study the development of tourism in the province of Gora (Albania, Kosovo and Macedonia). Through the identification and promotion of their tourist

\footnotetext{
${ }^{1}$ Nazif Dokle, Për gorën dhe goranët, Prizren 2002, fq 12
} 
attractions. This scientific work aims at providing a modest contribution to the solution of the best models of sustainable tourism development in this region, with the sole purpose of the socio-economic development of the community in the place. Through this study will determine the role and importance of the model's for tour operators that operate with their own tourist activities in a competitive environment and who may face opportunities and risk that brings you the environment .Topic,, Coss-border Region Gora treasure between the three states", has the subject of study: Identify the problematic that exists for the development of tourism. To foster / compile cross-border projects with objective tourism and increasing cooperation between the countries where the province of Gora is located; To propose the marketing instruments of destination and development of tourism product etc. The realization of these objectives will significantly affect the positive effects of tourism development.

\section{Research Methodology}

The complexity of sustainable tourism development means that rather than applying a single search method needed different methods to be combined. Generally, research in the tourism sector is dominated by quantitative research, led largely by determining its economic significance (Jennings, 2001). The methodology of this scientific work is based on literature study and empirical study. such as: books, scientific journals, official publications, websites. The review of secondary resources also served to formulate questionnaires, in collecting primary data at the later stage of the study. in collecting primary data at the later stage of the study. While the empirical study consists in addressing the Gora Province as a tourist destination, the model of its development should be aim towards sustainability. In the case study analysis, a combination of quantitative and qualitative methods of study was done. Primary data are based on qualitative research and quantitative research. Methodological aspects include a range of analyzes assessments, statistics, conclusions etc. During drafting scientific work quantitative data collection method is used, by means of a questionnaire. This has helped to compare the various variables used to test the hypotheses put forward. Another method used in this scientific work is the descriptive method, through which is described the sustainable tourism model from the practice of different authors, and the current state of tourism in the Province of Gora. 


\section{Research questions and hypotheses}

Gora is a significant market for the tourism industry in Albania and Kosovo, with a sector that aims to increase the benefits from the local, regional and international tourist market. But for a long-term result of this industry, it is necessary to follow a model that will produce impacts from which all stakeholders will benefit. Based on the not only descriptive but also explanatory nature of this study, hypotheses have been raised:

H1: Tourism is a priority for the economic, social and environmental development of the province of Gora H1.1: The benefits provided by tourism have positive effects on the economy and the social cultural outcomes of the inhabitants of the province of Gora. H2: Gore's cultural heritage, competitive regional advantage through co-operation. H2.1: Creating opportunities for developing joint cross-border projects and community participation in the development of tourist destinacion

\section{Study Limitations}

During the drafting of this topic, we have faced a number of problems and difficulties in finding some information, mainly statistical. Tourism inflow statistics have never been collected and hotels do not keep track of their hosts' profile, such as nationality, residence or number of nights spent at the hotel. The area studied is not very studied in terms of tourism, which means we will encounter a lack of qualitative and quantitative data. Lack of political, economic and social cohesion in the Gora Gorge that extends into three states. Lack of tourism strategies, where tourism in Gora Province is a priority. Difficulties have also been encountered in collecting information about the two villages of Gora, which are in Macedonia. There are significant shortcomings in the data to present the economic indicators of the Gora Region in the three states.

\section{Gora Region as an attractive tourist destination, influencing the socio-economic welfare.}

Tourist destinations are the motivating offer for tourists because of the fact that they represent a country, a city, an area, etc., with many opportunities for tourism. Today they are in continuous expansion and as such they are becoming more and more competitive in the tourist market. The tourist perceives the entire destination as a product and judges it as a whole rather than differentiating the services of the supplying companies. The destination system may consist of three different levels of its actors in the manner of their collection, due to the divergent orientation of the interests that are important for the management of the destination and which are reflected in the following:

Individual enterprises (micro level): Private enterprises and private services present the tourist destination to a micro level. The medium-sized destination: where in this case, the tourist destination appears as a network in the form of an organization, where all individual enterprises are interconnected, this is done in a comprehensive inter-organizational unit and is considered as a unit at the micro level. 


\section{Tourist Destinations in Kosovo, Sharr Mountain Range}

The surrounding protected areas and sites are some of the most beautiful locations in the world that attract many visitors from Europe and the world. They are important components of the economy, contributing over 15 billion euro annually to employment and other services for peoples of Europe. According to the International Union for Conservation of Nature (IUCN), the categorization of the Sharr National Park is classified as a protected area of Category II. These areas with potential for winter tourism also offer water attractions, with many water springs, streams, varied vegetation and scenic landscapes that can be used for summer recreation as well. Dragash can develop a sustainable tourism economy through a partnership between the public sector, the private sector and civil society to protect the environment, increase employment and provide entrepreneurship opportunities and social and economic benefits.

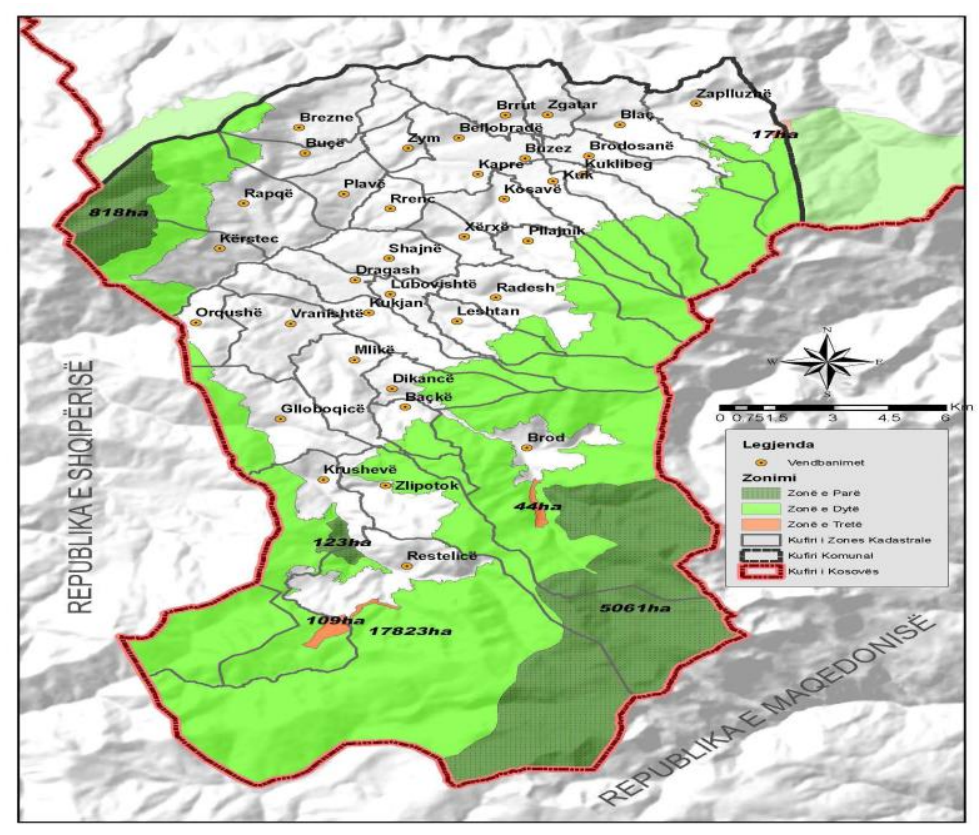

the Dragash economy, which will contribute to improving the long-term economic and social development which foresees that by 2031 the tourism sector will represent 10-15\% of Dragash economy

\section{Tourist destination in Gora Province (Albania), Shishtavec Village}

Shishtaveci is part of the Kukes Region, Gora Province, the part of Albania and is a great potential for the tourism economy. Šestavaci is located in the northeast of Albania, at a height of $1260 \mathrm{~m}$ above sea level. 


\section{Tourist Map of the Shishtavec Mountains}

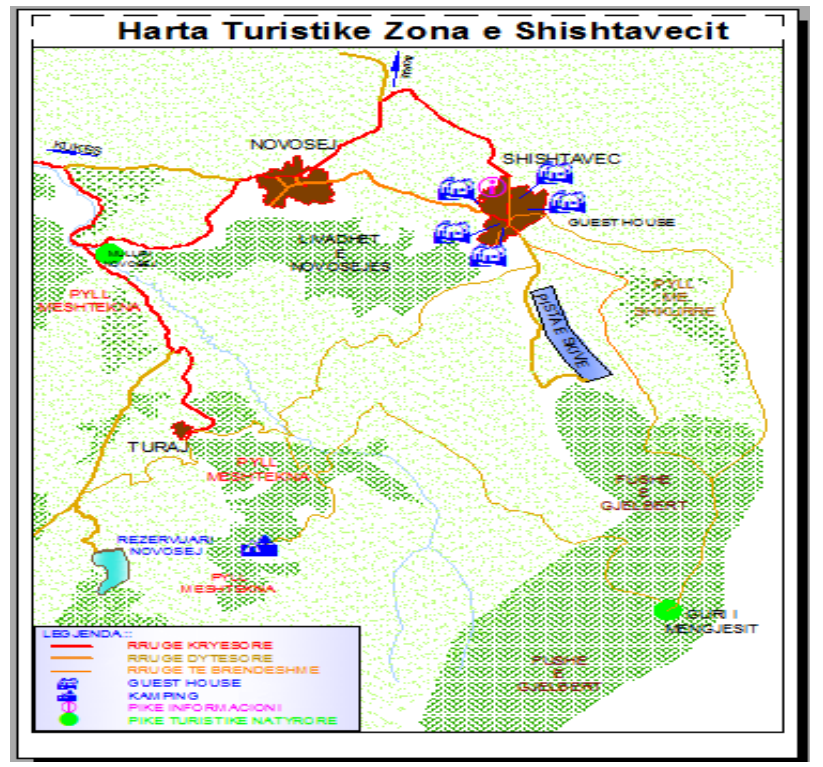

Shishtaveci, offers its potential, very important nature, history and culture in the field of tourism. It is precisely these potentials that qualify the tourism right in this area as one of the most economical economic activities. Shishtaveci is known as the village of champion skiers. "The tradition of skiing exercise is early. The Shishtavec plate offers the opportunity to run ski races during the winter and during summer an incredibly noble elite sport, hippie. Shishtaveci is the natural beauty spot. The reliquary represents contrasts between mountains and valleys, thus creating very attractive natural landscapes for the eye of tourists. There are potential for hip-hop sport and why it's not yet done properly. Often, this kind of sport has been developed on holiday occasions by the village's own residents. Shishtaveci has obvious advantages because of the position, human, economic and cultural potentials.

\section{Demand-supply factors affecting the development of tourism.}

Recent research by the World Tourism and Travel Council, conducted in 2010, showed that the tourism industry has made a direct contribution to global GDP growth by 3.3\%, reaching a figure of 1,770 billion USD. During 2011 it is forecast that this growth will be further strengthened by $4.5 \%$ per annum (USD 1,850 billion). On the other hand, given the wider impact of the economy on global GDP, it is expected that this will contribute this year by $9.1 \%$, which means $\$ 5,987$ billion and the creation of 258 million new jobs. This economic growth will face many challenges for the private and state sectors as a result of the demands to reduce government debts and confront the rise in oil and other commodity prices, while the tourism sector in particular is expected to be the main engine that will bring this economic development ${ }^{2}$. The role of tourism is increasingly recognized by the governments of all regions of the world as one of the main indicators of economic growth. Research by the World Tourism and Travel Council clearly shows the potential of tourism to reinvigorate the global economy, reduce unemployment, helping to ensure sustainable development and mitigate poverty. Economic factors are among the most important factors that affect the growth or decrease of tourism demand, as they are crucial in choosing or not of a tourist destination. 


\section{Attitudes and perceptions of tourism influences}

About the ways they can benefit, we list: renting rooms / houses; imitations from the sale of local

Ndikimet socio-kulturore

-Ndikime pozive Ndikime negative

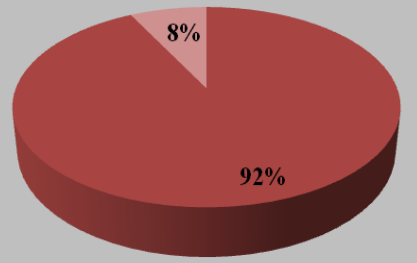
products, such as: medicinal plants, handicrafts and supplies Over $90 \%$ of respondents believe that tourism development is accompanied by positive impacts on the economy and sociocultural life.

\section{Home Gaps}

$74 \%$ of respondents recognize the tourist potentials of the Gora Province, the tourism industry in the Gora region is largely dependent on public goods, such as diversity of relief forms, cultural heritage, natural landscapes and intangible cultural values, Residents, the tourist sector, see it not merely as an opportunity for economic development of the locality, but are also aware of its socio-cultural impacts. $45 \%$ of those who visit Gora's province receive information through friends, indicating that the province is not properly promoted in the media or included in various tourist tours. From the choice of accommodation, we see that we are dealing more with a market that does not require adventure but requires security and convenience. According to the findings and statistical analysis, hypotheses 1 and 2 are confirmed, this means that tourism has positive effects on economic and social development in the Gora Province.Përfundimi dhe rekomandime

Among the most important goals of this topic is the possibility of tourism development, as a factor of economic development of Gora in accordance with the sustainable environment, as well as the social demands; - analytical and synthetic values of the anthropogenic and human resources and their landscape will activate economic development; Pointing to the need for a tourist area, the full introduction of this crane in the economic markets, we will be able to contribute to the promotion of the environment and the possibility of selling the tourist product. Furthermore, it will be aimed at identifying the factors that limit the development of tourism and other economic activities in this area. Setting the development priorities in the area of economic policy and determining the strategic directions of development (tourism, agriculture, livestock); Identifying conflictual relations between economy and ecology, with a view to protecting the environment and rational management of natural resources. This study confirms the theoretical framework of literature that sustainability is an increasingly important issue in the tourism industry. As discussed in the study, we can conclude that the tourism development of a destination depends to a great extent on the involvement and role of its main actors. Gora Province has very good conditions for the development of rural tourism, but the local population still does not have the proper experience to develop this type of tourism. There are joint 
arrangements between the Gores in Albania and Kosovo. There is no cooperation with the part of Macedonia.

\section{Reference}

Nazif Dokle, Për gorën dhe goranët, Prizren 2002, fq 12

Avdia, B. ( 2013). "Bashkëpunimi ndërkufitar si mundësi për zhvillimin e turizmit në krahinën Etnogjeografike të Lumës dhe Gorës.". Prishtine: Studime gjeografike 15.

World Travel\&Tourism Council. (2011). F.1

IUCN Lista e Kombeve të Bashkuara e Parqeve Nacionale dhe Zonave të Mbrojtura, 1990.

UNDP. (2013). "Plani Zhvillimor Komunal për Komunën e Dragashit 2013 - 2023. Dragash .

RASP, BTD, ALB-aid. (2012). "Plani i zhvillimit i Komunës Shishtavec". Kukës.

UNDP Kosovë. (2011). Malet e Dragashit, Kosovë: Udhëzues për Turizëm Natyror dhe Shëtitje. Dragash: XHAD Studio.

Avdia, B. (2011 ). "Turizmi në zonat malore si mundësi për zhvillimin e qendrueshëm në Komunën e Shishtavecit”. Tiranë: Studimet Albanologjike. 